\title{
COMMENTS
}

\section{Conflict and Aggregation: Appointing Institutional Investors as Sole Lead Plaintiffs Under the PSLRA}

\author{
R. Chris Heck $\dagger$
}

Suppose that a corporation's stock price falls after management reveals unexpected problems with a new product. Investors who bought stock before the announcement only to see the value of their investments collapse file numerous lawsuits on behalf of the class of investors. ${ }^{1}$ The court then consolidates these actions into a single case. The next step is to select lead plaintiffs to conduct the litigation; this selection ${ }^{2}$ is governed by the recently enacted Private Securities Litigation Reform Act of 1995 ("PSLRA"). ${ }^{3}$ The PSLRA establishes a rebuttable presumption that the moving plaintiff who satisfies Federal Rule of Civil Procedure 23 and has the largest financial interest should be appointed lead plaintiff. ${ }^{4}$ In addition, the Act's legislative history

$\dagger$ B.A. 1997, Amherst College; J.D. Candidate 2000, The University of Chicago.

Plaintiffs can bring these suits under several statutes, but the most frequently used is Section 10(b) of the Securities Exchange Act of 1934, Pub L No 73-404, 48 Stat 891, codified at 15 USC §§ 78a-78lll (1994 \& Supp 1996), as implemented by the Securities and Exchange Commission's ("SEC") Rule 10b-5, which makes deceptive statements or material omissions unlawful. 17 CFR § 240.10b-5 (1998). An implied private cause of action has been recognized under Section 10(b) and Rule 10b-5. See Kardon v National Gypsum Co, 73 F Supp 798 (E D Pa 1947). For a general overview of civil liability for securities fraud, see Louis Loss and Joel Seligman, Fundamentals of Securities Regulation 969-1160 (Little, Brown 3d ed 1995).

215 USC §§ 77z-1(a)(3), 78u-4(a)(3) (Supp 1996).

3 Pub L No 104-67, 109 Stat 737 (1995), codified at 15 USC $\S \S 77 z-1-78 u-5$ (1994 \& Supp 1996). The PSLRA modified both the Securities Act of 1933, 15 USC $\S \S 77$ a et seq, and the Securities Exchange Act of 1934, 15 USC $\S \S 78 a$ et seq. While the language and numbering of the lead plaintiff provision is identical for both Acts, this Comment will cite both in order to aid the reader in finding the relevant language.

4 15 USC $\S \S 77 z-1(a)(3)(B)(i i i), 78 u-4(a)(3)(B)(i i i)$. 
suggests that Congress sought to encourage institutional investors to serve as lead plaintiffs.

Assume that two plaintiffs move to be lead plaintiff: a group of about two hundred individuals who lost an average of $\$ 5,000$ after selling their stock (a total loss of $\$ 1$ million) and a public pension fund that lost $\$ 700,000$ but has sold only about a third of its original holdings in the company. The individuals' attorneys present several arguments for appointing their clients as lead plaintiff. First, the aggregated group of individual investors has a larger financial stake in the litigation-the key test under the PSLRA. ${ }^{5}$ Second, the pension fund cannot adequately represent the class because it is more sophisticated than most investors, has an independent fiduciary duty to the state pensioners, and continues to be a stockholder.

The group of individual stockholders also files a motion in the alternative asking to be appointed co-lead plaintiff with the pension fund in the event the court rejects its motion to be appointed sole lead plaintiff. The pension fund, for its part, claims it incurred the largest single loss of any investor and thus has the largest financial stake in the litigation. Moreover, it denies that its representation will be inadequate, arguing that its sophistication is irrelevant under case law, its fiduciary duties to the pensioners will not make its decisionmaking any different from any other lead plaintiff, and it will fulfill its duties to the class despite its continued ownership of stock in the defendant corporation.

This hypothetical case illustrates one of the central questions left unresolved by the PSLRA: when should institutional investors be appointed the lead plaintiff in securities litigation? This Comment provides a framework for determining when institutional investors should be appointed as sole lead plaintiffs, when groups of individuals or institutions should be aggregated as a single plaintiff, and when multiple plaintiffs should be appointed co-lead plaintiffs. Part I summarizes the lead plaintiff provision of the PSLRA. Part II provides an analysis of decisions interpreting the PSLRA and relevant pre-PSLRA law. Part III explains when groups of institutions or individuals should be treated as a single plaintiff and argues that such aggregation should rarely be used. Part III also examines other objections raised to institutions' motions to be appointed lead plaintiff and

${ }^{5} 15$ USC $\S \S 77 \mathrm{z}-1(\mathrm{a})(3)(\mathrm{B})(\mathrm{iii})(\mathrm{I}), 78 \mathrm{u}-4(\mathrm{a})(3)(\mathrm{B})(\mathrm{iii})(\mathrm{I})$ (stating that the lead plaintiff is presumed to be the plaintiff who files a motion, has the largest financial interest in the litigation, and satisfies the requirements for maintaining a class action). 
finds these objections generally without merit, except for those based on the conflict between current and former stockholders.

\section{The Language, History, AND Policy OF THE LEAD PLAINTIFF PROVISION}

Before Congress passed the PSLRA, many academics and commentators argued that most private securities fraud suits harmed rather than helped corporations and their stockholders. ${ }^{6}$ Although the actions often lacked merit, corporations frequently settled them to avoid the substantial costs, such as discovery, posed by even baseless claims. ${ }^{7}$ Because these actions were groundless for the most part, their settlement served no useful deterrent effect; rather, settlement simply increased the costs of raising capital. Moreover, even in meritorious actions, the plaintiffs who comprised the securities fraud class received little compensation for the fraud perpetrated upon them ${ }^{8}$ - the primary beneficiaries were the plaintiffs' attorneys, who were perceived as lining their pockets at the expense of corporate America. ${ }^{9}$

- See, for example, Tim Oliver Brandi, The Strike Suit: A Common Problem of the Derivative Suit and the Shareholder Class Action, 98 Dickinson L Rev 355, 357 (1994) ("Practical experience and empirical studies have led courts and commentators to conclude that in the United States, shareholder litigation appears to be more open to abuse by strike suits brought for their mere nuisance and settlement value than other fields of civil litigation."); Ralph K. Winter, Paying Lawyers, Empowering Prosecutors, and Protecting Managers: Raising the Cost of Capital in America, 42 Duke L J 945, 948-53 (1993) (arguing that most securities fraud cases are frivolous and have the detrimental effect of increasing the cost of capital); John V. Rindlaub, At Last, Litigation Reform, Seattle Times B5 (Jan 4, 1996) (describing such suits as abusive and a "tax on innovation"); Ed McCracken, The New Threat to High-Tech Firms, San Fran Chron A19 (June 28, 1995) (arguing that meritless securities fraud suits had nearly bankrupted several small high-tech companies and imposed unnecessary costs on others).

' See Blue Chip Stamps v Manor Drug Stores, 421 US 723, 740-43 (1975) (stating that large discovery costs to the corporate defendant in securities fraud actions increase the chances of "vexatious" litigation); Janet Cooper Alexander, Do the Merits Matter? A Study of Settlements in Securities Class Actions, 43 Stan L Rev 497, 548-50 (1991) (arguing that high discovery costs encourage defendants to settle meritless securities litigation); Neal $\mathrm{H}$. Klausner, Note, The Dynamics of Rule 11: Preventing Frivolous Litigation by Demanding Professional Responsibility, 61 NYU L Rev 300, 306 (1986) (stating that securities fraud suits are often filed regardless of the merits because even a substantial settlement is less costly than litigation).

3ee Private Securities Litigation Reform Act of 1995, S Rep No 104-98, 104th Cong, 1st Sess 1, 6 (1995), reprinted in 1995 USCCAN 679, 685 (citing studies that investors recover only seven to fourteen cents for each dollar lost because of securities fraud).

- See, for example, Julie Schmit, Lerach: Silicon Valley's Nightmare, USA Today 1B (Oct 23, 1996) (describing one of the most prominent plaintiff's attorneys and including statistics on the small amount investors recovered compared to the percentage fees lawyers charge); McCracken, The New Threat, San Fran Chron at Al9 (cited in note 6) (arguing that securities fraud suits do not benefit shareholders because such suits just shift wealth among different groups of shareholders, but the plaintiff's attorney receives a large fee with every such shift). See generally John C. Coffee, Jr., Understanding the Plaintiff's 
Before the PSLRA, most courts appointed the first plaintiff to file a complaint as the lead plaintiff. ${ }^{10}$ The lead plaintiff, or more likely her attorney, was responsible for certifying the class and conducting any pre-certification settlement negotiations. If the case did not settle before the certification hearing, and the lead plaintiff survived the defendant's challenges on the question of whether she satisfied the requirements of Federal Rule of Civil Procedure 23, then the lead plaintiff became the class representative of the certified class and her attorney conducted the trial. Because the counsel for the lead plaintiff often received a larger share of the attorneys' fees upon settlement or verdict than the attorneys for other class members, lawyers had strong incentives for their clients to become lead plaintiffs; therefore, they would file complaints as quickly as possible and waste little time in determining whether the suit was meritorious. ${ }^{11}$ To this end, plaintiff's law firms used "professional plaintiffs," people who owned a few shares of stock in each of a large number of companies and who were willing to have their names attached to complaints. Having professional plaintiffs available eliminated the need for lawyers to wait for clients to come to them. ${ }^{12}$ Such plaintiffs had long-standing relationships with particular firms and exercised little control over the attorneys who were, theoretically, acting on their behalf. Thus, the attorneys were essentially free to accept or reject settlements and otherwise make key decisions during the course of litigation without consulting their client. ${ }^{13}$

Attorney: The Implications of Economic Theory for Private Enforcement of Law through Class and Derivative Actions, 86 Colum L Rev 669, 718-20 (1986) (explaining that a plaintiff's attorney may implicitly collude with defendant directors, who are often personally subjected to a derivative suit when the corporation is sued under the federal securities laws, to provide the bulk of any recovery for the fraud from the corporation, and thus indirectly the shareholders, rather than from the directors' personal wealth).

${ }^{10}$ See $S$ Rep No 104-98 at 11 (cited in note 8).

"See Private Securities Litigation Reform Act of 1995, HR Conf Rep No 104-369, 104th Cong, 1st Sess 31, 33 (1995), reprinted in 1995 USCCAN 730, 732 (finding that the "first to file" rule led to a lack of diligence in drafting complaints).

${ }^{12}$ See S Rep No 104-98 at 9 (cited in note 8). Such plaintiffs were motivated by the fact that courts often awarded bonuses to the lead plaintiffs in addition to (and far greater than) their proportional shares of the recovery. See id at 10.

${ }^{13}$ Theoretically, class action attorneys are bound by the rules of ethical responsibility to consult their clients and represent their interests. See ABA Model Rules of Professional Conduct 1.2 (1997) ("A lawyer shall abide by a client's decisions concerning the objectives of representation."); Rule 1.4 (stating that a lawyer will keep the client informed about the case, supply information the client requests, and explain the case so that the client can make informed decisions). However, some plaintiff's attorneys openly flout these responsibilities. See, for example, William P. Barrett, I Have No Clients, Forbes 52 (Oct 11, 1993) (Though ostensibly an attorney for named plaintiffs, Lerach is not really accountable to them, instead pretty much deciding on his own whom to sue and when to settle and for how much. 'I have the greatest practice of law in the world,' he acknowledges once telling 


\section{A. Requirements of the PSLRA}

The PSLRA's lead plaintiff provision fundamentally changed the way lead plaintiffs are appointed. After the PSLRA, any plaintiff who files a complaint must also file a sworn certification stating that he has reviewed the complaint, was not told to purchase the stock at issue by his counsel, and will not accept any payment from settlement or verdict beyond his pro rata share of damages. ${ }^{14}$ The first plaintiff who files a complaint must also notify others of the action and the claims it asserts by publication in a national business publication or wire service, in order to give other plaintiffs an opportunity to move to become lead plaintiff. ${ }^{15}$ Anyone in the plaintiff class may apply to be lead plaintiff; the court must choose the lead plaintiff from among the applicants within ninety days of the notice ${ }^{16}$ or, if the court consolidates actions, as soon after consolidation as practicable. ${ }^{17}$ Once appointed, the lead plaintiff chooses lead counsel. ${ }^{18}$

The PSLRA creates a presumption that the court should select as lead plaintiff the "person or group of persons" who (1) filed the complaint or moved to be appointed, (2) has the largest financial interest in the litigation, and (3) satisfies the requirements of Federal Rule of Civil Procedure 23. ${ }^{19}$ Other aspiring lead plaintiffs may rebut this presumption if they can show that the plaintiff with the greatest financial stake in the litigation will not adequately protect the interests of the class or is subject to unique

a meeting of corporate directors. 'I have no clients."). Also, the use of a single figurehead plaintiff, who would predictably defer to the attorney on all decisions in order to obtain the bonus named plaintiffs received before the PSLRA, gave the attorney near-complete control over the litigation. For example, William Lerach used retiree William Weinberger as the plaintiff in ninety lawsuits from 1989-92. See McCracken, The New Threat, San Fran Chron at A19 (cited in note 6); Schmit, Lerach, USA Today at 1B (cited in note 9). In any case, Congress believed that plaintiff's attorneys were controlling securities fraud litigation without being constrained by their clients. See S Rep No 104-98 at 6 (cited in note 8) ("[The PSLRA] contains several provisions to transfer primary control of private securities litigation from lawyers to investors. . . . [The PSLRA] prohibits several abusive practices ... that have enabled lawyers to exercise nearly total fiat over the course of private securities litigation.").

1415 USC $\S \S 77 z-1(a)(2)(A), 78 u-4(a)(2)(A)$.

is 15 USC $\S \S 77 z-1(a)(3)(A), 78 u-4(a)(3)(A)$.

t6 15 USC $\S \S 77 z-1(a)(3)(B)(i), 78 u-4(a)(3)(B)(i)$.

15 USC $\$ \S 77 \mathrm{z}-1(\mathrm{a})(3)(\mathrm{B})(\mathrm{ii}), 78 \mathrm{u}-4(\mathrm{a})(3)(\mathrm{B})(\mathrm{ii})$.

${ }^{18} 15$ USC $\$ \S 77 \mathrm{z}-1(\mathrm{a})(3)(\mathrm{B})(\mathrm{v}), 78 \mathrm{u}-4(\mathrm{a})(3)(\mathrm{B})(\mathrm{v})$.

${ }^{19} 15$ USC $\S \S 77 \mathrm{z}-1(\mathrm{a})(3)(\mathrm{B})(\mathrm{iii})(\mathrm{I}), 78 \mathrm{u}-4(\mathrm{a})(3)(\mathrm{B})(\mathrm{iii})(\mathrm{I})$. FRCP 23(a) requires that: (1) the class be sufficiently numerous, (2) the class members present common questions of law or fact, (3) the claims or defenses of the representatives be typical of the class as a whole, and (4) the class representatives will fairly and adequately protect the interests of all members. FRCP 23(a). Also, in securities fraud suits, questions common to the group must predominate over questions affecting individuals. FRCP 23(b). 
defenses. ${ }^{20}$ Before conducting discovery into such issues, a plaintiff must demonstrate a reasonable basis for believing the presumptive lead plaintiff is inadequate. ${ }^{21}$ Finally, professional plaintiffs are prohibited: no plaintiff can serve as lead plaintiff in more than five securities fraud class actions within a three-year period, "[e]xcept as the court may otherwise permit, consistent with the purposes" of the PSLRA. ${ }^{22}$

\section{B. Structure and Legislative History of the PSLRA}

Both the structure of the PSLRA and its legislative history show that Congress designed it to achieve two interrelated objectives: (1) to encourage institutional investors to become lead plaintiffs and (2) to reduce the amount of control attorneys wielded over securities fraud litigation.

The text of the PSLRA does not expressly state that courts should prefer institutional investors as lead plaintiffs; however, the legislative history demonstrates that this was the goal Congress had in mind. ${ }^{23}$ In deciding to favor institutional investors as lead plaintiffs, Congress relied on a law review article by professors Elliott Weiss and John Beckerman. ${ }^{24}$ The core of the article's argument is that, unlike individual investors who often stand to recover only small amounts from securities fraud litigation, institutions are likely to have suffered large losses from any fraud. This potential for significant recovery gives an institutional investor a greater incentive to monitor its lawyer and ensure that the attorney's actions promote the best interest of the class. ${ }^{25}$

Weiss and Beckerman expected this monitoring to yield three benefits. First, the plaintiff class would receive more favorable settlement terms because the institutions would prevent the attorneys from settling on terms that benefited the lawyers at the

${ }^{20} 15$ USC §§ 77z-1(a)(3)(B)(iii)(II), 78u-4(a)(3)(B)(iii)(II).

${ }^{21} 15$ USC $\S$ 77z-1(a)(3)(B)(iv), 78u-4(a)(3)(B)(iv).

$=15$ USC $\S \S 77 z-1(a)(3)(B)(v i), 78 u-4(a)(3)(B)(v i)$. Congress intended, by giving the court discretion, to prevent this section from applying to institutional investors. See HR Conf Rep No 104-369 at 35 (cited in note 11).

${ }^{2}$ See S Rep No 104-98 at 11 (cited in note 8) ("TT]he Committee intends to increase the likelihood that institutional investors will serve as lead plaintiffs."); HR Conf Rep No 104-369 at 34 (cited in note 11) ("[T] Conference Committee seeks to increase the likelihood that institutional investors will serve as lead plaintiffs.").

${ }^{24}$ Elliott J. Weiss and John S. Beckerman, Let the Money Do the Monitoring: How Institutional Investors Can Reduce Agency Costs in Securities Class Actions, 104 Yale L J 2053 (1995). The Senate Report specifically states that "[t]his [Weiss and Beckerman] article provided the basis for the 'most adequate plaintiff' provision." S Rep No 104-98 at 11 n 32 (cited in note 8).

${ }^{25}$ Weiss and Beckerman, 104 Yale L J at 2095 (cited in note 24). 
expense of their clients. ${ }^{26}$ Second, fewer meritless suits would be filed because the institutional plaintiffs would be more sensitive to the costs frivolous suits impose on publicly traded companies. ${ }^{27}$ Third, appointing institutional investors as lead plaintiffs would reduce the fraction of class actions that were settled. Actual litigation of cases would create more precedents, providing corporations with greater certainty of how to comply with Rule 10b-5 and other antifraud statutes as well as providing more authority for courts to dismiss meritless suits. ${ }^{28}$ Investors would be the direct beneficiaries of this greater certainty because corporations' legal costs would be reduced, leaving more profits to be distributed to the shareholders. Congress concluded that once certain procedural obstacles were removed, ${ }^{29}$ institutions would have the incentive to serve as lead plaintiffs and help fulfill these goals.

A number of specific provisions facilitate the appointment of institutional investors as lead plaintiffs. The PSLRA prohibits a person from being a lead plaintiff or its agent in more than five securities actions within a three-year period, unless the court decides such an appointment would be "consistent with the purposes of this section." ${ }^{30}$ In addition, the award to the class representative must be proportional to his financial interests in the litigation, plus any reasonable costs. ${ }^{31}$ These restrictions were designed to prevent the use of professional plaintiffs. ${ }^{32}$ Likewise, the requirement that any movant for lead plaintiff file a sworn certificate stating that he did not purchase the stock at the direction of his counse $l^{33}$ further demonstrates the PSRLA's purpose of reducing the influence of attorneys in securities litigation. Given the large amounts of investments controlled by institutions, ${ }^{34}$ the

${ }^{2}$ Id at 2121-22.

${ }^{27}$ Id at 2122-23.

${ }^{23}$ Id at 2123.

These procedural obstacles were the "first to file" rule, id at 2098-100, lack of notice, id at 2100-01, and the threat that defendants could conduct discovery to determine whether class representatives satisfied the requirements of Rule 23, id at 2101-03. The PSLRA cures these problems. The "first to file" rule is cured by 15 USC $\S \S 77 \mathrm{z}$ 1(a)(3)(B)(iii)(I), 78u-4(a)(3)(B)(iii)(I). See text accompanying note 19. The "lack of timely notice problem" is cured by 15 USC $\S \S 77 \mathrm{z}-1(\mathrm{a})(3)(\mathrm{A}), 78 \mathrm{u}-4(\mathrm{a})(3)(\mathrm{A})$. See text accompanying note 15. Finally, the "threat of discovery problem" is cured by 15 USC $\S \S 772$ 1(a)(3)(B)(iv), 78u-4(a)(3)(B)(iv). See text accompanying note 21.

${ }^{30} 15$ USC $\S \S 77 z-1(a)(3)(B)(v i), 78 u-4(a)(3)(B)(v i)$.

${ }^{31} 15$ USC $\S \S 77 \mathrm{z}-1(\mathrm{a})(4), 78 \mathrm{u}-4(\mathrm{a})(4)$.

${ }^{32}$ The lead plaintiff chooses the lead counsel. 15 USC $\$ \S 77 z-1(a)(3)(B)(v), 78 u-$ $4(a)(3)(B)(v)$. Therefore it was common for professional plaintiffs to work with a particular law firm, guaranteeing the firm an appointment as lead counsel.

35 15 USC $\S \S 77 z-1(a)(2)(A), 78 u-4(a)(2)(A)$.

${ }^{34}$ See HR Conf Rep No 104-369 at 34 (cited in note 11) (finding that institutional investors hold about 51 percent of the equity market). 
statutory presumption that the plaintiff with the largest financial interest in the litigation is the lead plaintiff shows that Congress intended to aid institutions in being appointed as lead plaintiff. ${ }^{35}$

Additional legislative history reinforces the purposes identified above in the statutory structure and language. Among other evidence, ${ }^{36}$ the Senate and House Conference Reports state that Congress sought and intended "to increase the likelihood that institutional investors will serve as lead plaintiffs." ${ }^{37}$ Congress intended that control of securities fraud litigation be returned to the shareholders:

The House and Senate Committees heard evidence that abusive practices committed in private securities litigation include ... the manipulation by class action lawyers of the clients whom they purportedly represent. ... [This legislation] protects investors who join class actions against lawyerdriven lawsuits by giving control of the litigation to lead plaintiffs with substantial holdings of the securities of the issuer. ... These provisions are intended to increase the likelihood that parties with significant holdings in issuers, whose interests are more strongly aligned with the class of shareholders, will participate in the litigation and exercise control over the selections and actions of plaintiff's counsel. ${ }^{38}$

Not all members of Congress supported the lead plaintiff provision of the PSLRA. Critics objected for two reasons. ${ }^{39}$ First,

315 USC $\S \S 77 \mathrm{z}-1(\mathrm{a})(3)(\mathrm{B})(\mathrm{iii})(\mathrm{I})(\mathrm{bb}), 78 \mathrm{u}-4(\mathrm{a})(3)(\mathrm{B})(\mathrm{iii})(\mathrm{I})(\mathrm{bb})$ (stating that the most adequate plaintiff is the person or group of persons that "in the determination of the court, has the largest financial interest in the relief sought by the class").

${ }^{36}$ See, for example, $S$ Rep No 104-98 at 11 (cited in note 8) ("The Committee believes that increasing the role of institutional investors will ultimately benefit the class and assist the courts."). See also id at $\mathbf{4 0}$ (additional views of Senators Sarbanes, Bryan, and Boxer) ("The new procedures contained in the bill for selecting a lead plaintiff in class actions are designed to encourage participation by institutional investors."); HR Conf Rep No 104-369 at 34 (cited in note 11) ("The Conference Committee believes that increasing the role of institutional investors in class actions will ultimately benefit shareholders and assist courts by improving the quality of representation in securities class actions. ... Institutional investors and other class members with large amounts at stake will represent the interests of the plaintiff class more effectively than class members with small amounts at stake.").

${ }^{37} \mathrm{~S}$ Rep No 104-98 at 11 (cited in note 8); HR Conf Rep No 104-369 at 34 (cited in note 11).

${ }^{3}$ HR Conf Rep No 104-369 at 31-32 (cited in note 11). See also id at 35 ("TT] Conference Committee expects that the plaintiff will choose counsel rather than, as is true today, counsel choosing the plaintiff"); S Rep No 104-98 at 6 (cited in note 8) ("S. 240 is intended to empower investors so that they, not their lawyers, control securities litigation."); id at 10 ("The lead plaintiff should actively represent the class. The Committee believes that the lead plaintiff-not lawyers-should drive the litigation.").

${ }^{39}$ See generally Jill E. Fisch, Class Action Reform: Lessons from Securities Litigation, 
institutional investor control of securities fraud litigation would reduce the amount that small individual investors could recover because institutional investors, given their close ties to defendant corporations, would "dismiss cases or enter into sweetheart settlements" that ignored small investor concerns. ${ }^{40}$ Second, the lead plaintiff provision disserved the principal policy behind class actions: to permit those with small losses to aggregate into a class with a sufficiently high expected recovery to induce an attorney to take the case. ${ }^{41}$ The majority of Congress mollified these detractors ${ }^{42}$ by making the presumption that the movant with the largest financial interest should be lead plaintiff rebuttable upon a showing by another plaintiff that the presumptive plaintiff will not adequately represent the class or is subject to unique defenses. ${ }^{43}$

\section{JUDICIAL INTERPRETATIONS OF THE LEAD PLAINTIFF PROVISION}

In those cases where institutional investors have sought to be lead plaintiffs in securities fraud actions, courts generally have appointed them as sole lead plaintiffs. Judges often have relied on the legislative history of the PSLRA, seeking to promote the policies identified in the Weiss and Beckerman article. However, a few courts either have appointed institutions co-lead plaintiffs alongside other plaintiffs or have appointed groups of individuals to the lead position, rather than an institution.

This Part first examines the adequacy and typicality objections raised against institutional investors. This Part then analyzes when courts appoint co-lead plaintiffs and when they aggregate the losses of separate plaintiffs to determine who has the largest financial interest in the litigation. ${ }^{44}$ While the lack of

39 Ariz L Rev 533, 541-50 (1997) (advancing a number of arguments against encouraging institutional investors to control securities fraud class actions).

* Private Securities Litigation Reform Act of 1995, S 240, 104th Cong, 1st Sess, in 141 Cong Rec S 8915 (June 22, 1995) (statement of Senator Bryan) (calling the provision the "most affluent plaintiff" requirement and stating that it would "simply wipe out average investors who are defrauded"). See also Fisch, 39 Ariz L Rev at 548-49 (cited in note 39) (noting that institutional participation in securities litigation may increase the risk of collusion between the institutional investor and the corporate defendant).

"141 Cong Rec at S 8915 (cited in note 40). See generally Phillips Petroleum Co $v$ Shutts, 472 US 797, 809 (1985) (stating that one purpose of class actions is "to pool claims which would be uneconomical to litigate individually").

${ }^{12}$ See $S$ Rep No 104-98 at 40 (cited in note 8) (additional views of Senators Sarbanes, Bryan, and Boxer).

15 USC $\S \S 77 z-1(\mathrm{a})(3)(\mathrm{B})(\mathrm{iii})(\mathrm{II}), 78 \mathrm{u}-4$ (a)(3)(B)(iii)(II).

" Note the difference between appointing co-lead plaintiffs and aggregating plaintiffs into a group, discussed in Part II.C. Co-lead plaintiffs are groups who have filed sepa- 
precedents makes generalizing difficult, most courts have refused to appoint co-lead plaintiffs but have permitted aggregation.

\section{A. Challenges Based on Typicality and Adequacy}

The usual challenge to the appointment of an institutional investor as lead plaintiff is that the institution is neither a typical nor adequate plaintiff, as explicitly required by the Act. ${ }^{45}$ Typicality requires that the class representative have claims based on the same legal theories as those of the class ${ }^{46}$ and not be subject to unique defenses not applicable to other class members. ${ }^{47}$ Adequacy requires that the class counsel selected by the class representative be sufficiently competent to conduct the litigation and that class members do not have antagonistic interests. ${ }^{48}$ Objections to the appointment of institutional investors as lead plaintiffs have been based on three characteristics of institutional investors: their sophistication, their preexisting independent fiduciary duties, and their potential conflicts of interest. This subpart describes these challenges and surveys court decisions both before and after the PSLRA was enacted.

\section{Sophisticated investors and reliance.}

Plaintiffs opposing the appointment of institutional investors as lead plaintiffs argue that institutions are sophisticated investors and thus cannot properly represent a class comprised of other, smaller investors. ${ }^{49}$ Institutions make their investment decisions using prospectuses and reports on the industry or corporation provided by financial services companies and discussions with the company's management, while individual investors generally rely only on the market..$^{50}$ Thus, movants opposing the institution argue that the institution was more likely to have been aware of any potential problems with the company's future

rately for the lead plaintiff position, each with its own law firm. The members of an aggregated group file together seeking lead plaintiff status; all members will be represented by a single firm.

${ }^{4} 15$ USC $\S \S 77 \mathrm{z}-1(\mathrm{a})(3)(\mathrm{B})(\mathrm{iii})(\mathrm{II})(\mathrm{aa})-(\mathrm{bb}), 78 \mathrm{u}-4(\mathrm{a})(3)(\mathrm{B})(\mathrm{iii})(\mathrm{II})(\mathrm{aa})$-(bb).

${ }^{46}$ See Alpern $v$ Utilicorp United, Inc, 84 F3d 1525, 1540 (8th Cir 1996).

${ }^{47}$ See Hanon v Dataproducts Corp, 976 F2d 497, 508 (9th Cir 1992) (listing cases).

${ }^{43}$ See In re Drexel Burnham Lambert Group, Inc, 960 F2d 285, 291 (2d Cir 1992); Lerwill v Inflight Motion Pictures, Inc, 582 F2d 507, 512 (9th Cir 1978).

${ }^{49}$ See Gluck v Cellstar Corp, 976 F Supp 542, 547-48 (N D Tex 1997) (rejecting plaintiff's argument that an institutional investor is an inadequate representative because it will consider the long-term interests of the defendant); Chan v Orthologic Corp, No CIV 96-1514 PHX RCB, order at 8-11 (D Ariz, Dec 17, 1996) (rejecting plaintiff's argument that institutional investor was inappropriate representative because it was sophisticated).

${ }^{50}$ Chan, No CIV 96-1514 PHX RCB, order at 9. 
earnings and thus are not entitled to rely on the market price, like unsophisticated individuals are.

Before the PSLRA, courts routinely rejected the argument that an institutional investor's sophistication prevented it from meeting the requirements to serve as lead plaintiff. ${ }^{51}$ Courts reasoned that because plaintiffs may show reliance by using the fraud-on-the market theory, ${ }^{52}$ differences between potential lead plaintiffs based on their relative levels of sophistication are irrelevant. According to the fraud-on-the-market theory, stock prices rapidly incorporate public information and all plaintiffs are presumed to rely on such prices (and any incorrect or fraudulent information) when purchasing or selling stock..$^{53}$ The PSLRA has not altered this rule. In fact, in Gluck $v$ Cellstar Corporation, ${ }^{54}$ the court went even further and reasoned that because the legislative history of the PSLRA suggested a congressional intent to favor institutional investors, plaintiffs cannot challenge institutional investors as lead plaintiffs based on characteristics that are common to all institutional investors, such as sophistication. ${ }^{55}$

\section{Independent fiduciary duties.}

Plaintiffs also challenge the appointment of certain institutional investors, such as pension funds, as lead plaintiffs by asserting that their independent fiduciary duties to beneficiaries preclude them from adequately representing the interests of absent class members. The institution's fiduciary duty to those not

${ }^{31}$ See, for example, Hanon, 976 F2d at 506, 508-09 (holding that the sophistication of an investor does not make that investor subject to a unique defense that would render the investor atypical for purposes of FRCP 23(a)(3), but disqualifying the particular plaintiff because he was a professional plaintiff); Gilbert $v$ First Alert, Inc, 904 F Supp 714, 719-20 (N D Ill 1995) (holding that the sophistication of an investor does not make that investor subject to a unique defense that would render the investor atypical for purposes of FRCP 23(a)(3)).

${ }_{52}$ See Basic, Inc $v$ Levinson, 485 US 224, 247 (1988) (holding that relying on the market price of a security satisfies the reliance requirement of $10 \mathrm{~b}-5$ actions). Defendants (or challengers to movants for lead plaintiff) face a difficult task in rebutting this presumption of reliance. Id at 248-49 (holding that the defendant must produce evidence that "severs" the link between the alleged misrepresentation and either the price at which the plaintiffs transacted or the plaintiff's decision to transact at all).

${ }^{53}$ Id at 241-42, 247 (explaining the fraud-on-the-market theory and approving its use in Rule 10b-5 actions). See also Daniel R. Fischel, Efficient Capital Markets, The Crash, and the Fraud on the Market Theory, 74 Cornell L Rev 907 (1989) (describing and analyzing the fraud-on-the-market theory).

st 976 F Supp 542 (N D Tex 1997).

so Id at 548. See also Chan, No CIV 96-1514 PHX RCB, order at 11 (declining to apply precedents pre-dating the PSLRA that held that institutional investors are atypical of the class because the legislative history of the PSLRA demonstrates that it was designed to favor institutions). 
involved in the case might lead it to end the litigation or to settle whenever the costs of litigation exceed the amount that it, as class representative, could recover itself. However, as the representative of the class, the institution would also have a fiduciary duty to the class ${ }^{56}$ that would require it to pursue the litigation whenever the total projected recovery to the class as a whole-an amount greater than its own individual recovery-exceeded the litigation costs.

A recent case illustrates this tension. In In re Oxford Health Plans, Inc, Securities Litigation, ${ }^{57}$ the Public Employee's Retirement Association of Colorado ("ColPERA") moved to be appointed as sole lead plaintiff. ColPERA, a state public employees retirement association, ${ }^{58}$ owed government pensioners a fiduciary duty to invest their money in the most profitable manner. ${ }^{59}$ Given this duty, the court feared that ColPERA, which had agreed to pay part of the litigation costs rather than having its attorneys advance all costs as is typical, would have a greater incentive to settle because of its fiduciary duties if those costs became too large, even though its attorneys had agreed to advance the costs if ColPERA became unwilling to keep paying. ${ }^{60}$ Thus, the court added other class members as co-lead plaintiffs to alleviate this tension. ${ }^{61}$

Few courts have accepted the argument that an institutional investor's independent fiduciary duty to its beneficiaries prevents it from serving as lead plaintiff..$^{22}$ One court has observed that a representative always has an incentive to end the litigation if the costs exceed his probable recovery, regardless of whether he has

${ }^{56}$ See, for example, Cohen $v$ Beneficial Industrial Loan Corp, 337 US 541, 549 (1949) (finding that the shareholder who brings derivative suit acts as fiduciary because he sues "not for himself alone, but as representative of a class comprising all who are similarly situated").

${ }^{57} 182$ FRD 42 (S D NY 1998).

s Public institutions are frequent securities fraud plaintiffs. Other examples include the State of Wisconsin Investment Board in Gluck, $976 \mathrm{~F} \mathrm{Supp} \mathrm{at} \mathrm{543,} \mathrm{and} \mathrm{the} \mathrm{California}$ Public Employees Retirement System, the New York State Common Retirement Fund, and the New York City Pension Funds in In re Cendant Corp Litigation, 182 FRD 144, 146 (D NJ 1998).

${ }^{89}$ Oxford, $182 \mathrm{FRD}$ at 47.

${ }^{\infty}$ Id at 46.

${ }^{61}$ Id at 45-47.

¿2 See, for example, In re The Pittsburgh and Lake Erie Railroad Co Securities and Antitrust Litigation, 543 F2d 1058, 1067 (3d Cir 1976) (holding that indenture trustee with fiduciary duties to bondholders can bring a derivative action); Kaplan v Pomerantz, 131 FRD 118, 123 (N D Ill 1990) (holding that estate administrator was adequate class representative); Bennett v Tucker, 127 FRD 501, 507-08 (N D Ill 1989) (same); Shamberg v Ahlstrom, 111 FRD 689, 693-94 (D NJ 1986) (finding that executor of plaintiff's estate could proceed with securities fraud case despite alleged conflicts of interest). 
independent fiduciary duties. ${ }^{63}$ Moreover, most jurisdictions have relaxed their ethical rules prohibiting plaintiff's attorneys from advancing, or even being ultimately responsible for, the costs of the case. ${ }^{64}$ The client, and those to whom it may owe fiduciary duties, is rarely responsible for the costs of litigation ${ }^{65}$ and thus increasing costs would not require the client to settle or end the litigation prematurely. ${ }^{66}$

\section{Conflicts of interest.}

Another challenge raised against the adequacy of institutional investors as class representatives is that an institution's financial interest in the defendant corporation may be antagonistic to the interests of other class members. ${ }^{67}$ Institutional investors are more likely than individuals to continue to own at least some stock in a corporation that is being sued for securities fraud violations. ${ }^{68}$ Former stockholders have an incentive to claim as much recovery as possible, while present stockholders want to maximize the joint values of their recovery plus the value of the stock they still hold.

The two court decisions dealing with lead plaintiff conflict of interest situations since the passage of the PSLRA reach different outcomes. In Gluck, the court rejected the challenge, ${ }^{69}$ applying reasoning similar to the reasoning it applied to the sophistication argument: Congress's intent to favor institutional investors trumps the class action policy concern and prevents this chal-

"Kaplan, 131 FRD at 123.

${ }^{61}$ See Rand $v$ Monsanto Co, 926 F2d 596, 601-03 (7th Cir 1991) (vacating the trial court's dismissal of a class action because the class representative was unwilling to bear the entire cost of the litigation, invalidating the rule of the ABA's Model Code of Professional Responsibility requiring clients to be responsible for the costs of litigation insofar as the rule applies to class actions, and collecting local rules on attorney discipline).

${ }^{\infty}$ See generally S Rep No 104-98 at 6 (cited in note 8) ("[C]lass counsel usually advances the cost of litigation."). In Oxford, the institution represented that it would advance the entire costs of the litigation, but later limited this commitment, inviting the court to consider the problems that might arise if the institution ended its funding. 182 FRD at 46-47.

${ }^{\circ}$ See Weiss and Beckerman, 104 Yale L J at $2118 \mathrm{n} 316$ (cited in note 24) ("Any apparent conflict between an institution's fiduciary duties to its beneficiaries and a class representative's fiduciary duties to class members is illusory, at least if plaintiffs' attorneys are prepared to advance expenses for institutional investors as they now do for figurehead plaintiffs.").

${ }^{67}$ The requirements for representation under FRCP 23(a)(4) are that a class must not have antagonistic interests and the class counsel selected by the representative must be competent and qualified. See Drexel Burnham, 960 F2d at 291.

\& See Janet Cooper Alexander, Rethinking Damages in Securities Class Actions, 48 Stan L Rev 1487, 1503 (1996).

${ }^{\infty}$ Gluck, 976 F Supp at 548. 
lenge from succeeding. ${ }^{70}$ Moreover, the court reasoned that the institution's judgment about what recovery was appropriate would be more reliable than that of a plaintiff's attorney, who might want to maximize the immediate recovery. ${ }^{71}$

In In re Cendant Corporation Litigation, ${ }^{72}$ a conflict of interest was sufficient to disqualify a group of institutional investors from acting as lead plaintiff. The institutions that the court appointed co-lead plaintiffs had an investment of $\$ 300$ million in the underwriter of a challenged derivative instrument. ${ }^{73}$ The maximum the institutions could recover on the claim involving the derivative was under $\$ 7$ million. ${ }^{74}$ The court stated that "logic and simple mathematics" demonstrated that the institutions could not overcome the conflict of interest and adequately represent investors on these claims because the suit impaired their financial interest in the underwriter. ${ }^{75}$ While the defendant in question was the underwriter and not the issuing corporation, the court's reasoning suggests that if an institution maintained significant investments in a defendant corporation, the institution could not adequately represent, as lead plaintiff, a class of stockholders who had sold all of their stock in the corporation. ${ }^{76}$

Despite the appeal of the distinction between current and former shareholders, most pre-PSLRA decisions side with Gluck and reject this argument. ${ }^{77}$ Courts justify this outcome with several policy arguments. First, they conclude that the question of

\footnotetext{
${ }^{30}$ Id.

"I Id.

72 182 FRD 144 (D NJ 1998).

${ }^{73}$ Id at 149.

"Id.

73 Id.

${ }^{76}$ However, the court in Cendant later rejected this position. See Cendant, 182 FRD at $150-52$

" See Blackie v Barrack, 524 F2d 891, 908-11, 911 n 27 (9th Cir 1975) (rejecting the argument that conflicts between present and former shareholders required immediate class decertification); Herbst $v$ International Telephone and Telegraph Corp, 495 F2d 1308, 1314 (2d Cir 1974) (finding that a conflict of interest does not exist between members of a plaintiff class in a securities fraud suit merely because some members retained stock and others sold their stock); Ziemack v Centel Corp, 164 FRD 477 (N D Ill 1995) (containing a lengthy analysis of the merits and policies of excluding current shareholders from class membership and ultimately rejecting such a policy). However, Judge Walker, who frequently presides over securities fraud suits, has concluded that the different interests between current and former shareholders may create sufficiently severe conflicts to prevent adequate representation. Consequently, his court requires plaintiffs to produce information about the extent of conflicts between current and former shareholders before certifying the class. In re California Micro Devices Securities Litigation, 168 FRD 257, 271-72 (N D Cal 1996); In re Clearly Canadian Securities Litigation, 875 F Supp 1410, 1422 (N D Cal 1995); In re Seagate Technology II Securities Litigation, 843 F Supp 1341, 1362-64 (N D Cal 1994).
} 
damages is peripheral because proving the allegations of the complaint is the core of any suit and damages are a secondary consideration. ${ }^{78}$ Second, courts reason that this conflict between plaintiffs' interests is speculative: plaintiffs who continue to own stock will not necessarily want a lower recovery from litigation. ${ }^{79}$ Third, courts note that the interest in recovery in a securities fraud case outweighs any concerns about damaging the company.$^{80}$ Fourth, courts often note that to give weight to this putative conflict would make class actions difficult to maintain, primarily because it might cause class representatives to fail the adequacy requirement of Federal Rule of Civil Procedure $23(a)(4){ }^{81}$

\section{B. Co-lead Plaintiffs}

Another way the courts accommodate concerns about the adequacy and typicality of institutional investors is to appoint colead plaintiffs. In $O x f o r d{ }^{82}$ the court permitted distinct groups of plaintiffs to control jointly the course of the litigation by appointing co-lead plaintiffs, ${ }^{83}$ on the ground that the plain language of the PSLRA permitted such joint appointments. ${ }^{84}$ The court reasoned that, when the institutional investor with the largest financial interest was burdened by an independent fiduciary obligation, co-lead plaintiffs would ensure a broad representation of the absent class members; it would also permit the joint lead plaintiffs to pool resources and experience. ${ }^{85}$ The court opined that appointing multiple lead plaintiffs would increase, rather than decrease, client control over the attorneys. ${ }^{86}$

Oxford, however, is an outlier. Most courts reject the option of appointing co-lead plaintiffs. ${ }^{87}$ They recognize that although

${ }^{73}$ See Blackie, 524 F2d at 909; Jenson v Continental Financial Corp, 404 F Supp 806, 811 (D Minn 1975).

${ }^{79}$ See Walsh $v$ Chittenden Corp, 798 F Supp 1043, 1054 (D Vt 1992) (finding that plaintiff who retains shares in defendant corporation has no conflict of interest with those who sold their shares because damages will be measured the same for both types of shareholders).

${ }^{\circ}$ See Herbst, 495 F2d at 1314; Welling $v$ Alexy, 155 FRD 654, 663 (N D Cal 1994).

"See, for example, Ziemack, 164 FRD at 481-82.

182 FRD 42 (S D NY 1998).

Id at 43.

as Id at 47. For an example of language in the PSLRA that could support appointing co-lead plaintiffs, see id.

${ }^{35}$ Id at $49-50$.

${ }^{\circ}$ Id at 49.

" See, for example, In re Milestone Scientific Securities Litigation, 183 FRD 404, 41718 (D NJ 1998); In re Advanced Tissue Sciences Securities Litigation, 1998 US Dist LEXIS 16926, *16-19 (S D Cal); Gluck, 976 F Supp at 549-50. 
some language of the PSLRA seems to permit aggregation because it refers to the presumptive lead plaintiffs in the plural as well as the singular, ${ }^{88}$ other language (by referring to the lead plaintiff only in the singular) suggests ruling out joint appointments. ${ }^{89}$ Moreover, these courts explain that joint appointments detract from the congressional goal of transferring power from attorneys to their clients in securities fraud cases; ${ }^{90}$ joint appointments also increase delay and litigation costs. ${ }^{91}$

\section{Aggregation}

A separate question is when courts should permit individuals or institutions to form groups and have their individual losses aggregated for purposes of determining who has "the largest financial interest in the relief sought by the class." ${ }^{\text {" }} 2$ The PSLRA's language is not helpful in answering this question because it does not define "financial interest." The legislative history of this provision is similarly uninformative. ${ }^{94}$ Courts have interpreted the PSLRA's aggregation language in three ways: (1) permitting any number of plaintiffs to aggregate, (2) aggregating only a limited number of individuals or institutions, or (3) refusing to permit aggregation.

Some courts permit any number of plaintiffs to aggregate their financial interests when determining what group has the largest financial interest. They rely on the language of the PSLRA to reach this result, reasoning that the plural "group of persons" permits such aggregation. ${ }^{95}$ Some courts appoint all of

see Milestone, 183 FRD at 417. The PSLRA states that "the court shall adopt a presumption that the most adequate plaintiff . . . is the person or group of persons . . . 15 USC $\S \S 77 z-1(a)(3)(B)(i i i)(I), 78 u-4(a)(3)(B)(i i i)(I)$. See also Part II.C.

See Milestone, 183 FRD at 417-18.

so See id at 417-18; Gluck, 976 F Supp at 549.

's See Advanced Tissue Sciences, 1998 US Dist LEXIS 16926 at *17; Reiger $v$ Altris Software, Inc, 1998 US Dist LEXIS 14705, *18 (S D Cal).

2215 USC $\$ \S 77 z-1(a)(3)(B)(i i i)(I)(b b), 78 u-4(a)(3)(B)(i i i)(I)(b b)$.

${ }^{23}$ Several courts have suggested that four factors are relevant to determining which plaintiff has the largest financial interest: "(1) the number of shares purchased during the class period; (2) the number of net shares purchased during the class period; (3) the total net funds expended during the class period; and (4) the approximate losses suffered during the class period." In re Olsten Corp Securities Litigation, 3 F Supp 2d 286, 295 (E D NY 1998). See also Milestone, 183 FRD at 413; Lax v First Merchants Acceptance Corp, 1997 US Dist LEXIS 12432, * 17 (N D Ill).

sowever, the congressional reports use singular language when discussing the most adequate plaintiff, implying that Congress did not intend for aggregation to occur frequently. See.HR Conf Rep No 104-369 at 34 (cited in note 11) (referring to "the member" of the purported class when determining who should be appointed as lead plaintiff and "the shareholder" in a discussion of rebutting the presumption of the most adequate plaintiff).

$\infty 15$ USC $\S \S 77 z-1(a)(3)(B)(i i i)(I), 78 u-4(a)(3)(B)(i i i)(I)$. 
the members of the aggregated group as lead plaintiffs ${ }^{96}$ while one has appointed only a limited number of group members to serve as lead plaintiffs. ${ }^{97}$ The court that appointed only a limited number from the group to serve as lead plaintiffs recognized that one of the primary policies behind the PSLRA is to reduce the influence of attorneys and that having numerous lead plaintiffs conflicts with this goal. ${ }^{98}$ Relying on the "group of persons" language, one court appointed an aggregated group as lead plaintiff rather than appointing the group that included the plaintiff with the largest single loss. ${ }^{99}$

The second approach is to aggregate only a limited number of individual or institutional investors who file together and specifically request to be named lead plaintiff. Courts following this approach combine the losses of the plaintiffs with the largest of several individual claims and reduce the size of a proposed group to this number. ${ }^{100}$ They reason that this approach strikes a balance between the language of the PSLRA-which seems to place no limits on aggregation-and the policies that lay behind the statute. ${ }^{101}$ The courts further reason that these limited groups of plaintiffs can still effectively monitor the lead counsel's performance, ${ }^{102}$ whereas a larger group would complicate the litigation and increase costs. ${ }^{103}$

Under the last approach, the court simply denies any aggregation and appoints the single investor with the largest financial stake as the sole lead plaintiff. Denying aggregation altogether is a minority position; apparently only the Southern District of New

${ }^{9}$ See Reiger, 1998 US Dist LEXIS 14705 at *13-14; Olsten Corp, 3 F Supp 2d at 295; Lax, 1997 US Dist LEXIS 12432 at *8-9, *25; D’Hondt $v$ Digi International Inc, 1997 US Dist LEXIS 17700, *19 (D Minn); Malin v IVAX Corp, No CIV 96-1843 MORENO, order at 3, 7 (S D Fla, Oct 31, 1996).

${ }^{n}$ See Advanced Tissue Sciences, 1998 US Dist LEXIS 16926 at *22-23 (aggregating losses of approximately two hundred-fifty plaintiffs for purposes of determining what group had the largest financial interest, but appointing only six members of that group as lead plaintiffs).

Id at $* 19-23$.

${ }^{\circ}$ See Reiger, 1998 US Dist LEXIS 14705 at *11-14.

${ }^{100}$ See Oxford, 182 FRD at 44-46 (limiting a group of approximately thirty-five plaintiffs to three individuals who had suffered about eighty-five percent of the group's losses); In re Reliance Acceptance Group, Inc, 1998 WL $388260,{ }^{\star} 1$ n $3,{ }^{\star} 3$ n 11 (W D Tex) (considering from a group of sixty-one plaintiffs losses of only six to serve as lead plaintiffs based on who suffered the most financial loss); Chill $v$ Green Tree Financial Corp, 181 FRD 398, 403-04, 409 (D Minn 1998) (limiting group of almost three hundred investors to six to determine which plaintiff had the largest financial interest).

${ }^{101}$ See Oxford, 182 FRD at 45-46; Chill, 181 FRD at 408-09.

${ }^{102}$ Oxford, 182 FRD at 46.

${ }^{100}$ Chill, 181 FRD at 408. 
York, in In re Donnkenny Inc Securities Litigation, ${ }^{104}$ has followed this approach. ${ }^{105}$ The court found that the congressional policy in favor of having plaintiffs, rather than their attorneys, drive securities litigation would be ill-served by aggregation. ${ }^{106}$

\section{APPOINTING INSTITUTIONAL INVESTORS AS SOLE LEAD PLAINTIFF}

This Part proposes a framework for courts to use when interpreting the lead plaintiff provision of the PSLRA. First, the legislative history and structure of the PSLRA indicate its purpose to increase the control of the client plaintiffs over securities litigation, in particular through encouraging institutional investors to serve as lead plaintiffs. Ambiguous phrases in the statute should be read in light of this purpose. ${ }^{107}$ Second, courts should not aggregate plaintiffs or appoint co-lead plaintiffs because doing so frustrates Congress's intent that litigation be controlled by institutional investors rather than by lawyers. Third, courts should continue to reject most of the challenges to appointments of institutional investors as lead plaintiffs based on the typicality or adequacy requirements. Sometimes, however, courts should recognize that the conflict between current and former shareholders is so severe that any single class representative who attempts to represent both sets of shareholders will be inadequate. In these cases, courts should appoint co-lead plaintiffs by determining the value of the stock a proposed lead plaintiff holds in a defendant corporation.

A. The PSLRA's Purpose and Legislative History Should Be Considered When Interpreting the Statutory Language

The legislative history of the PSLRA indicates that Congress sought to achieve two goals in enacting the lead plaintiff provision: to encourage the appointment of institutional investors as lead plaintiffs and, relatedly, to reduce attorney control over se-

${ }^{104} 171$ FRD 156 (S D NY 1997).

${ }^{100}$ Id at 157-58 (appointing the institutional investor with the largest single loss even though the plaintiffs had requested the appointment of two institutions and four individuals).

${ }^{106} \mathrm{Id}$.

${ }^{100}$ See, for example, Allied-Bruce Terminix Companies v Dobson, 513 US 265, 278 (1995) (relying on congressional purpose in interpreting an ambiguous phrase in the Federal Arbitration Act); Spectrum Sports, Inc v McQuillan, 506 US 447, 457 (1993) (rejecting a lower court test of monopolization that would offend the "purpose and policy" of the Sherman Act). 
curities class actions. ${ }^{108}$ As a first principle, courts applying the PSLRA should draw on this legislative history and purpose in interpreting its provisions. The Supreme Court has often held that the statute as a whole, and the purpose that is derived from that language, should be used when interpreting specific words in a statute. ${ }^{109}$ Moreover, where the language of a statute is not clear, legislative history, if it clearly reveals congressional intent, may be used to interpret the words or phrases. ${ }^{110}$ In legal briefs submitted to the courts, the SEC has endorsed the use of both of these principles to interpret the PSLRA. ${ }^{111}$

A common objection to the use of legislative history or purpose in interpreting statutes is that if Congress actually intended a statute to accomplish some purpose, that purpose would have been explicitly written into the statute. This objection may be answered regarding both of the purposes of the lead plaintiff provisions of the PSLRA. First, given the use of professional plaintiffs

\footnotetext{
${ }^{108}$ See Part I.B.

${ }^{100}$ See Holloway $v$ United States, $119 \mathrm{~S} \mathrm{Ct} 966,969$ (1999) ("In interpreting the statute at issue, '[w]e consider not only the bare meaning' of the critical word or phrase 'but also its placement and purpose in the statutory scheme."), quoting Bailey $v$ United States, 516 US 137, 145 (1995); Lewis v United States, 118 S Ct 1135, 1139 (1998) (rejecting literal interpretation of statutory language where that interpretation "would dramatically separate the statute from its intended purpose"); John Hancock Mutual Life Insurance Co v Harris Trust and Savings Bank, 510 US 86, 94-95 (1993) (interpreting statutory language is done by "examin[ing] first the language of the governing statute, guided not by a 'single sentence or member of a sentence, but look [ing] to the provisions of the whole law, and to its object and policy"), quoting Pilot Life Insurance Co v Dedeaux, 481 US 41, 51 (1987) (citations omitted).

${ }^{10}$ See Hubbard $v$ United States, 514 US 695, 703 (1995) ("In the ordinary case, absent any indication that doing so would frustrate Congress's clear intention or yield patent absurdity, our obligation is to apply the statute as Congress wrote it.") (emphasis added), quoting BFP v Resolution Trust Corp, 511 US 531, 570 (1994) (Souter dissenting); Kaiser Aluminum \& Chemical Corp $v$ Bonjorno, 494 US 827, 835 (1990) ("The starting point for the interpretation of a statute is the language of the statute itself. Absent a clearly expressed legislative intention to the contrary, that language must ordinarily be regarded as conclusive."') (emphasis added), quoting Consumer Product Safety Commission v GTE Sylvania, Inc, 447 US 102, 108 (1980).

Whether and when legislative history should be used is the subject of much academic controversy. Compare Stephen Breyer, On the Uses of Legislative History in Interpreting Statutes, 65 S Cal L Rev 845 (1991) (arguing that legislative history should be used to determine the purposes of legislation and interpret ambiguous statutes with that purpose in mind), with William N. Eskridge, Jr., The New Textualism, 37 UCLA L Rev 621 (1990) (arguing that the Supreme Court should rely less on legislative history and instead concentrate on developing interpretive rules to apply to statutory texts).

"'See Memorandum of SEC as Amicus Curiae, In re Milestone Scientific Securities Litigation, No 98-3404 (AJL), at 6-8 (D NJ 1998), available online at $<$ http://www.sec.gov/news/legal/mileston.txt> (visited July 23, 1999); Memorandum of SEC as Amicus Curiae, LaPerriere $v$ Vesta Insurance Group, No 98-AR-1407-S, at 11-13 (N D Ala 1998), available online at <http://www.sec.gov/news/legal/vestabrf.txt> (visited July 23,1999 ).
} 
with little or no stake in the litigation before the passage of the PSLRA, ${ }^{112}$ the provisions restricting professional plaintiffs and requiring the appointment of the lead plaintiff with the largest financial interest are the clearest means by which Congress could use statutory language to show its purpose to transfer control of securities fraud litigation from attorneys to their clients. Second, Congress's most likely reason in not explicitly favoring institutional investors in the statute was to permit courts to appoint an individual investor where that single individual has a greater financial interest than any other plaintiff (including institutions). Such an individual plaintiff would likely have the same incentive and ability to monitor class counsel as well as the same interest in the market as a whole as institutional investors. ${ }^{113}$ However, given the large holdings of most institutional investors, they will usually have the largest financial interest of any plaintiff in securities fraud litigation.

\section{B. Limiting Aggregation and Co-lead Plaintiffs}

Permitting courts to aggregate the financial losses of individual plaintiffs to determine what group has the largest financial interest in the litigation is one way in which the congressional purpose of favoring institutional investors can be frustrated. This subpart examines how aggregation shifts control of securities fraud litigation from investors to their attorneys and how aggregation makes it less likely that institutional investors will be appointed as lead plaintiffs. For similar reasons, this subpart also argues that courts should not appoint co-lead plaintiffs.

The interpretation of the phrase "person or group of persons" in the section of the PSLRA that determines who is the presumptive lead plaintiff ${ }^{114}$ should be guided by the principles of statutory purpose and congressional intent discussed above. Some courts have argued that the plain meaning of this phrase permits the aggregation of all plaintiffs who file together seeking to be named as lead plaintiff. ${ }^{115}$ However, such unlimited aggregation frustrates the purposes of the lead plaintiff provision of the

\footnotetext{
${ }^{112}$ See text accompanying note 12.

${ }^{113}$ Likewise, the arguments of this Comment should be understood to apply to a single individual where that individual has suffered the greatest loss of any investor.

${ }^{114} 15$ USC $\S \S 77 \mathrm{z}-1$ (a)(3)(B)(iii)(I), 78u-4(a)(3)(B)(iii)(I).

${ }^{115}$ See Reiger $v$ Altris, 1998 US Dist LEXIS 14705, *13-14 (S D Cal) ("While legislative history mentions the goal of increasing the involvement of institutional investors in securities litigation, there is no express provision in the Act limiting the rebuttable presumption to institutional investors. It is well settled that the plain language of the Act is controlling."); Oxford, 182 FRD at 47 ("In addition the plain language of the PSLRA expressly contemplates the appointment of more than one lead plaintiff").
} 
PSLRA. First, institutional investors normally either file alone $e^{116}$ or with a few other institutions, ${ }^{117}$ while individual investors normally file together in a large group. ${ }^{118}$ Thus, permitting aggregation would cause institutional investors to be appointed less frequently, frustrating the PSLRA's goal of having institutional investors serve as lead plaintiff more often. Second, as this subpart explains, permitting aggregation or the appointment of colead plaintiffs decreases the amount of control that clients can exercise over their attorneys.

1. Aggregation of individual losses shifts control of securities fraud litigation to the plaintiffs' attorneys.

Monitoring of class counsel by the lead plaintiff was one of the principal means through which Congress hoped to return control of securities fraud litigation to investors. ${ }^{119}$ In class actions, monitoring principally takes the form of the lead plaintiff ensuring that the class's attorney does not settle the suit simply because the cost of going to trial (which the attorney generally will bear) exceeds the expected benefits the attorney (but not the class) will receive. Attorney interests in this respect often diverge from class members' because conducting a trial places high costs on the lawyer that the class does not bear. Thus, attorneys have a strong incentive to settle even if more money for the class could be obtained through a verdict. ${ }^{120}$ In order to effectively monitor the attorney, the plaintiff must invest time to become familiar

${ }^{116}$ See Oxford, 182 FRD at 47 (Public Employee's Retirement Association of Colorado); Gluck, 976 F Supp at 543 (State of Wisconsin Investment Board).

${ }^{17}$ See In re Milestone Scientific Securities Litigation, 1998 US Dist LEXIS 19106, *4445 (D NJ) (four institutions and the two individuals who controlled the institutions); Cendant, 182 FRD at 147 (California Public Employees' Retirement System, New York State Common Retirement Fund, and New York City Pension Funds); Blaich v Employee Solutions, 1997 WL 842417 (D Ariz) (City of Philadelphia and Koala Productions).

${ }^{1 "}$ See, for example, In re Advanced Tissue Sciences Securities Litigation, 1998 US Dist LEXIS 16926, *22-23 (S D Cal) (approximately two hundred-fifty individuals filing as a group); Oxford, 182 FRD at 47 (thirty individuals and three small entities filing as a group); In re Reliance Acceptance Group, Inc, 1998 WL 388260, * 1 n 3 (W D Tex) (sixty-one individuals filing as a group); Chill $v$ Green Tree Financial Corp, 1998 US Dist LEXIS $11427, \star 8$ (D Minn) (almost three hundred individuals filing as a group).

${ }^{119}$ See HR Conf Rep No 104-39 at 32 (cited in note 11) ("These provisions [of the PSLRA] are intended to encourage the most capable representative of the plaintiff class to participate in class action litigation and to exercise supervision and control of the lawyers for the class.").

${ }^{120}$ See Weiss and Beckerman, 104 Yale L J at 2064-66 (cited in note 24) (noting that unlike regular litigation, where the client retains power to accept or reject settlement, the only constraints on a class action attorney's decision to settle are the rules of professional responsibility and court approval of the settlement under FRCP 23). 
with the law and the facts of the case and to make some judgment regarding the success the action will likely have at trial.

There are three ways in which aggregation reduces plaintiffs' incentives to monitor and transfers control from plaintiff investors to their lawyers. First, in an aggregated group, each individual plaintiff's claim may be too small to create an adequate incentive to monitor the attorney. Second, aggregation creates freerider and coordination problems among the aggregated plaintiffs that are difficult to control through monitoring. Third, aggregation divides decisionmaking among different persons.

Congress targeted the first and most obvious problem-inadequate incentives to monitor because of the small size of individual claims-by restricting the use of professional plaintiffs. ${ }^{121}$ As a general matter, a plaintiff has no incentive to monitor the attorney when the costs of doing so exceed what she anticipates recovering individually. Thus, monitoring may be inefficient if each plaintiff's cost of attorney monitoring is less than his share of the expected total recovery. This result holds even if the plaintiffs are aggregated into a group of five hundred other similar plaintiffs. Indeed, the SEC recognizes that institutions have monitoring abilities that are superior to most individual investors, ${ }^{122}$ and has argued that an aggregated group of unrelated individuals with relatively small losses will lack the "incentive or ability" to control class counsel. ${ }^{123}$ If courts permit aggregation, this group or some subsection of it may be appointed as lead plaintiff instead of an institution that has sufficient financial losses for it to engage in an efficient amount of monitoring. In general, courts that aggregate partially mitigate this problem by appointing from the aggregated group only those plaintiffs with large financial losses to serve as lead plaintiffs. ${ }^{124}$

The second problem-free-riding ${ }^{125}$-also occurs where multiple plaintiffs are present, regardless of whether they are aggregated or serve as co-leads. Believing that the other plaintiffs will monitor, each plaintiff has an incentive to spend less on attorney monitoring. At an extreme, each plaintiff will spend nothing on

\footnotetext{
${ }^{122}$ See 15 USC $\S \S 77 \mathrm{z}-1$ (a)(3)(B)(vi), 78u-4(a)(3)(B)(vi).

${ }^{12}$ Memorandum of SEC as Amicus Curiae, In re Milestone Scientific Securities Litigation at 10 (cited in note 111).

${ }^{123}$ Memorandum of SEC as Amicus Curiae, LaPerriere $v$ Vesta Insurance Group at 16 (cited in note 111).

${ }^{124}$ See text accompanying notes 95 and 98.

${ }^{125}$ For an overview of free-rider and other collective action problems, see Mancur OIson, The Logic of Collective Action: Public Goods and the Theory of Groups 9-16 (Harvard 1965) (describing how rationally self-interested individuals within a group will have an incentive not to spend resources to achieve goals that both the group and individual desire).
} 
attorney monitoring in the hopes that others will spend the optimum monitoring amount, perhaps leading to no monitoring at all. In addition, there may be coordination problems: even if each plaintiff is willing to spend a significant amount on attorney monitoring, each plaintiff's spending may be wasted duplicating the efforts of the other plaintiffs.

To some extent, disincentives to monitor are reduced when courts appoint fewer lead plaintiffs; one might argue that a few plaintiffs who agree to coordinate their efforts can control attorneys almost as well as one. However, because the costs invested by the plaintiffs are time rather than money, enforcing such agreements will be difficult. ${ }^{126}$ Thus, even with a small number of lead plaintiffs, the potential for free-riding could still be substantial. Thus, efficiency concerns dictate appointing only a single lead plaintiff. The plaintiff with the most at stake should be the one to serve as the lead-the result under the PSLRA if aggregation is not permitted.

The third problem is the most difficult to solve: appointing an aggregated group as lead plaintiff divides decisionmaking. Multiple lead plaintiffs can slow litigation when they disagree on how to proceed. Also, coordination problems among the lead plaintiffs will allow the attorney to have a disproportionate effect on litigation decisions. Given the congressional desire to reduce the role of attorneys in securities fraud litigation, this is a serious consequence of aggregation. When a single plaintiff and his attorney disagree, the plaintiff can nonetheless be confident that the attorney will act as his agent and follow his commands. By contrast, lead plaintiffs who are part of an aggregated group and disagree with their counsel have to oppose both their fellow lead plaintiffs and the lawyers, convincing both of them in order to change the course of litigation. As the lawyers add an extra imprimatur of authority to the position of the lead plaintiffs with whom the lawyers agree, the attorneys' decisions and choicesrather than their clients'-will have a stronger effect on the course of the litigation.

While often the attorney's advice might be in the best interests of the plaintiff investors, Congress found that this might not

\footnotetext{
${ }^{125}$ For example, if the duty of Lead Plaintiff $A$ is to ensure that the attorney obtains all documents from a particular defendant, few options for effective monitoring are present for the other plaintiffs. They could ask A directly, but A might be less than forthcoming regarding the existence or extent of his efforts. The other plaintiffs themselves could ensure the attorney obtains the documents, but this would result in duplicative efforts, and the tendency toward free-riding indicates that it is unlikely to occur.
} 
be true in securities fraud litigation. ${ }^{127}$ In drafting the PSLRA, it was presented with evidence that many attorneys who represented professional plaintiffs steered the litigation to serve their own (monetary) ends by settling cases when it suited their, rather than their clients', pecuniary interests. ${ }^{128}$ Aggregating lead plaintiffs who have only minor claims would perpetuate divided decisionmaking, which in turn allows the plaintiffs' lawyers to have undue control over the litigation.

The likelihood that attorneys will be able to unduly influence the course of litigation will occur regardless of the value of the claims the lead plaintiffs have. Having fewer lead plaintiffs will ameliorate the problem to some extent. The more clients there are, the greater the number of litigating positions they will adopt and thus the greater the chance that one of these positions will also be the position that maximizes the benefit to the attorney, possibly at the expense of the class. Fewer plaintiffs means fewer litigating positions, which gives the attorney less of an opportunity to choose a position that serves her interest to the detriment of the class, especially where the plaintiffs are sophisticated and able to choose the litigating positions that best serve the class's own interests. Taking this reasoning to its logical conclusion dictates the appointment of a single, sophisticated plaintiff who will make informed decisions and ensure that the attorney obeys these decisions.

\section{The proper scope of aggregation under the PSLRA.}

The text of the PSLRA does allow for aggregation by providing for appointment as lead plaintiff of the "person or group of persons" with the largest stake. ${ }^{129}$ However, limited aggregation, rather than unlimited, better satisfies the two objectives of the PSLRA-encouraging institutional investors to be lead plaintiffs and reducing attorney control over securities fraud actions. First, if courts refuse to aggregate, they are more likely to appoint institutional investors as lead plaintiffs rather than individual investors, primarily because any single individual investor is unlikely to own a portfolio as large as one held by an institutional investor. Second, appointing the single entity with the greatest financial interest as plaintiff will ensure that the lead plaintiff will di-

\footnotetext{
${ }^{127}$ See HR Conf Rep No 104-369 at 31 (cited in note 11) (finding that class action attorneys often manipulate the clients they purportedly represent).

${ }^{128}$ See S Rep No 104-98 at 9 (cited in note 8) (finding that although 93 percent of securities lawsuits settle at an average settlement cost of $\$ 8.6$ million, the actual "victims" receive only pennies on the dollar in damages).

${ }^{129} 15$ USC $\S \S 77 z-1(a)(3)(B)(i i i)(I), 78 u-4(a)(3)(B)(i i i)(I)$.
} 
rect the litigation rather than delegate that responsibility to its counsel because the plaintiff will have a sufficiently strong financial incentive to monitor the attorney and ensure that the attorney obtains the best settlement for the lead plaintiff and the class as a whole. And with only one plaintiff, no free-riding problems will occur within the class and decisionmaking will not be divided.

Courts should aggregate, however, in those instances when inefficient monitoring, free-riding, and diffuse decisionmaking will not affect the case. These difficulties are less likely to occur when the group requesting aggregation has close connections before the start of the litigation and has a developed structure through which its members can resolve disputes and delegate monitoring responsibilities. In this case, decisionmaking will effectively be united and free-riding costs minimized because the group already has a mechanism to coordinate its actions-including its relationship with its counsel. Indeed, the SEC in an amicus curiae brief has argued against aggregating plaintiffs, unless the aggregated group has an ability to monitor class counsel comparable to an institutional investor: ${ }^{130}$ absent a preexisting relationship among the plaintiffs, no more than five separate entities or individuals should be aggregated, and "the fewer the better." 131

A good example of a group satisfying such conditions for aggregation appears in In re Milestone Scientific Securities Litigation. ${ }^{132}$ There, the Gintel Group moved to be appointed as lead plaintiff. The group consisted of Robert Gintel, his wife, and five institutions. ${ }^{133}$ Robert Gintel made all final decisions for each of the group's institutions. ${ }^{134}$ Free-riding was prevented because Gintel, as leader, could enforce any monitoring duties he assigned and rely on support for the decisions he made.

3. Co-lead plaintiffs should not be appointed.

Courts should not appoint co-lead plaintiffs. As the SEC has argued, ${ }^{135}$ the PSLRA refers to a single lead plaintiff, and the

\footnotetext{
${ }^{130}$ Memorandum of SEC as Amicus Curiae, LaPerriere $v$ Vesta Insurance Group at 15 16 (cited in note 111).

${ }^{131}$ Id at 17.

132183 FRD 404 (D NJ 1998).

${ }^{133}$ Id at 418 (noting that Robert Gintel owned and controlled the five partnerships and investments groups that composed the Gintel Group).

${ }^{134}$ Id.

${ }^{10 \times}$ Memorandum of SEC as Amicus Curiae, La Perriere $v$ Vesta Insurance Group at 32 (cited in note 111).
} 
"group of persons" language indicates only that a group might be able to aggregate into a single lead plaintiff, not that separate lead plaintiffs should be appointed. ${ }^{136}$ Appointing co-lead plaintiffs creates the same problems as aggregation and poses additional problems. For example, those who want to serve as sole lead plaintiff may oppose having co-lead plaintiffs; ${ }^{137}$ if co-lead plaintiffs are nonetheless appointed, disputes between plaintiffs may result, lengthening the litigation and/or giving class counsel greater control. Courts appointing co-lead plaintiffs have relied on statutorily irrelevant policy goals that appear neither in the legislative history nor in the structure of the PSLRA, such as the diverse representation sought by the court in Oxford. ${ }^{138} \mathrm{Co}$-lead plaintiffs should only be used where the court believes that a single lead plaintiff cannot adequately represent all of the class members.

\section{Challenges Based on Adequacy and Typicality}

\section{General challenges.}

Under the PSLRA, potential plaintiffs can rebut the presumption that the person with the largest financial interest should be appointed lead plaintiff by demonstrating that that person does not have claims typical of the class or cannot adequately represent the class. ${ }^{139}$ In securities fraud cases, the courts have often narrowly interpreted the adequacy and typicality requirements in order to appoint institutions as lead plaintiffs.

The threshold for typicality, that the representative plaintiff's claims and defense be typical of the class's, is quite low. Institutions generally satisfy this requirement simply by alleging, as would an individual, the same causes of action and basic facts as would be used by other class members. ${ }^{140}$

Challengers argue that the independent fiduciary duties of institutional investors make them atypical of the class; but this argument can be applied equally well to all class representatives.

\footnotetext{
${ }^{136} \mathrm{Id}$ at $32-33$.

${ }^{135}$ For example, ColPERA vigorously fought the decision in Oxford to appoint co-lead plaintiffs. See Oxford, 182 FRD at 51 (denying ColPERA's motion for certification for immediate appeal); Metro Services Inc $v$ Wiggins, 158 F3d 162 (2d Cir 1998) (dismissing ColPERA's attempt to appeal the district court's decision under the collateral order doctrine).

${ }^{138}$ Oxford, 182 FRD at 49.

${ }^{139} 15$ USC $\S \S 77 z-1(a)(3)(B)($ iii)(II), 78u-4(a)(3)(B)(iii)(II).

${ }^{100}$ See Alpern v Utilcorp United, Inc, 84 F3d 1525, 1540 (8th Cir 1996) (holding that a class representative satisfies the typicality requirement if his claim arises from the same events as the class claims and is based on the same legal theories); Stewart $v$ Rubin, $948 \mathrm{~F}$ Supp 1077, 1088 (D DC 1996) (same).
} 
Whenever the costs of litigation exceed the expected gains of the class representative, the representative will seek to end or settle the litigation. ${ }^{141}$ If class actions are to be permitted at all, this argument must be rejected in motions for lead plaintiffs as well. Also, since attorneys normally advance the costs of litigation ${ }^{142}$ thereby eliminating the monetary costs to the lead plaintiffs-a plaintiff with the substantial financial interest needed to become lead plaintiff will be unlikely to end the litigation based on its costs.

Courts should also reject the argument against a presumptive plaintiff based on an institution's sophistication because all investors are presumed to rely on the market under the "fraudon-the-market" theory. ${ }^{143}$ Before and after the passage of the PSLRA, the fraud-on-the-market theory has been regularly applied to sophisticated investors such as institutions to reject claims that these investors are atypical because they rely on information other than market price. ${ }^{144}$ Basic, Inc $v$ Levinson ${ }^{145}$ draws no explicit distinction between sophisticated and unsophisticated investors. The examples supplied by the Supreme Court for rebutting the inference of reliance do not suggest that sophisticated investors who do not know the truth about the alleged misrepresentation are barred from using the fraud-on-the-market theory.

2. Adequacy of representation where the putative class includes both former and current stockholders.

A more serious adequacy of representation concern arises when a single plaintiff represents a class comprising both current and former stockholders. Adequate representation is a constitutional due process requirement that must be satisfied in order for the absent class members to be bound by the judgment or settlement. ${ }^{146}$ Former stockholders want to maximize damages while current stockholders want to maximize the sum of damages plus the value of their stock. Because of these conflicting interests re-

\footnotetext{
"see text accompanying note 63.

${ }^{142}$ See notes 65-66.

${ }^{143}$ See text accompanying note 52 .

'" See Hanon v Dataproducts Corp, 976 F2d 497, 506 (9th Cir 1992); In re Avon Securities Litigation, 1998 US Dist LEXIS 18642, *23-26 (S D NY).

${ }^{145} 485$ US 224 (1988).

${ }^{146}$ See Hansberry v Lee, 311 US 32, 45-46 (1940) (reversing a state supreme court's holding that the decision by a trial court on the validity of racially restrictive covenants was res judicata on both parties who owned land within the area specified by the covenant but were not represented before the trial court).
} 
garding the amount of damages awarded, it may be impossible for a single representative to provide adequate representation.

The standard justifications given for ignoring this conflict of interest are unpersuasive. ${ }^{147}$ Damages are the ultimate goal of a securities fraud suit, not a peripheral issue. Moreover, because securities fraud suits are settled more often than not, ${ }^{148}$ proving the elements of the cause of action at trial is often unnecessary. As a result, the amount of damages to be awarded is often the only real question to be resolved. ${ }^{149}$ Likewise, to characterize the conflict between former and current stockholders as speculative seems disingenuous since it is normal that the parties would act in their economic interests, which will cause conflicts when the amount of damages each group wants diverges. As one court said in refusing to appoint an institution as lead plaintiff when the institution had a clear conflict of interest with the former shareholders in the suit, "logic and simple mathematics speak louder" than any claims that the conflicted plaintiff will adequately represent the class. ${ }^{150}$

Whether a party's interest in recovery outweighs its concerns about damaging the company, as some courts have claimed, is an empirical question. One can easily imagine situations where that interest in recovery is not greater. The facts of Cendant, where the presumed lead plaintiffs had over $\$ 300$ million invested in the defendant investment bank but the most they could hope to recover was $\$ 6.4$ million, ${ }^{151}$ provide an example of when the interest in recovery was substantially less than the plaintiff's continuing interest in the defendant. While the conflict in Cendant arose because of the presumed lead plaintiff's interest in an investment bank rather than the issuing corporation, an institutional investor could have a similar disparity in financial interests in, and thus incentives not to seek full recovery from, a defending corporation. Finally, the possibility of creating two subclasses ${ }^{152}$-one composed of former stockholders and those who continue to own a small amount of stock and another composed of those with significant current holdings-would permit class actions to go forward while dealing with this conflict.

\footnotetext{
${ }^{147}$ See text accompanying notes $78-81$.

${ }^{145}$ See S Rep No 104-98 at 9 (cited in note 8) (finding that almost 93 percent of securities fraud lawsuits filed are settled).

${ }^{19}$ See Janet Cooper Alexander, The Value of Bad News in Securities Class Actions, 41 UCLA L Rev 1421, 1422 (1994).

${ }^{150}$ Cendant, 182 FRD at 149.

${ }^{151} \mathrm{Id}$.

${ }^{152}$ See FRCP 23(c)(4)(B) (permitting a proposed class to be divided into subclasses).
} 
The recent Supreme Court case of Amchem Products, Inc $v$ Windsor, ${ }^{153}$ a mass tort case, suggests by analogy that a class composed of both former and current stockholders cannot be represented adequately by a single representative. Amchem dealt with a challenge to a settlement made on behalf of all persons exposed to asbestos, ${ }^{154}$ no subclasses were used. ${ }^{155}$ Those objecting to the settlement (persons who were members of the class but not lead plaintiffs) argued that the settlement inadequately compensated class members who had been exposed to asbestos but who were not yet suffering health problems, although they might develop disease in the future. ${ }^{156}$ In decertifying the class, the Supreme Court reasoned in part that one group of representatives could not adequately represent both those plaintiffs who were currently afflicted and those who had been exposed but had not yet developed any symptoms. ${ }^{157}$ The Court found that the plaintiffs suffering current harm were interested in obtaining the maximum amount of money immediately, while the exposureonly plaintiffs wanted less compensation now in exchange for a fund set up to protect those who developed complications in the future. ${ }^{158}$ However, the Court strongly suggested that if the class had been divided into subclasses, with representatives of each subclass advancing only the interests of that subclass, then representation would have been adequate. ${ }^{159}$

The situation in Amchem is analogous to the conflict that arises in securities fraud suits between current and former stockholders. Former stockholders, like those currently injured because of asbestos exposure, want the largest amount of compensation possible and will try to maximize their recovery from litigation. Current stockholders, like those who were exposed to asbestos but had not yet developed disease, may accept some current compensation in the form of litigation recovery and defer some portion until the future when the corporation's stock value recovers. Under Amchem's logic, the same class representatives

\footnotetext{
${ }^{130} 521$ US 591 (1997).

${ }^{13}$ Id at 597.

${ }^{158}$ Id at 603 .

${ }^{136} \mathrm{Id}$ at 606.

${ }^{157} \mathrm{Id}$ at 624-28.

iss Id at 626 .

${ }^{150}$ Id at 627, quoting In re Joint Eastern and Southern District Asbestos Litigation, 982 F2d 721, 743 (2d Cir 1992) ("[W] here differences among members of a class are such that subclasses must be established ... the adversity among subgroups requires that the members of each subgroup cannot be bound to a settlement except by consents given by those who understand that their role is to represent solely the members of their respective subgroups."), modified on rehg as In re Findley, 993 F2d 7 (2d Cir 1993).
} 
cannot adequately represent both former and current stockholders. Therefore, the same lead plaintiff should not be permitted to represent both groups.

Normally, co-lead plaintiffs should not be appointed because their appointment contradicts the text of the PSLRA and frustrates its policies. ${ }^{160}$ However, this is one instance when the courts should interpret the phrase "person or group of persons"161 broadly to avoid the constitutional due process concerns that having former and current stockholders in the same group could create. ${ }^{162}$ Each co-lead plaintiff should represent only the interest of its class, that is, either those who continue to have a significant stock interest or those who do not. If the class is certified and the case is actually tried, the co-lead plaintiffs would represent separate subclasses. This procedure should satisfy the requirements of Amchem.

While separating plaintiffs who continue to own substantial amounts of stock from those who do not poses a line-drawing problem, courts are capable of resolving this. A court can determine whether a proposed lead plaintiff has substantial stock holdings in the defendant corporation by requiring the moving plaintiff to submit an affidavit stating the number of shares he owns. The court need not create myriad subclasses, ${ }^{163}$ but only two, based on whether the continued stock ownership is "substantial."

Separating those who have a substantial stock interest from those who do not is a more difficult problem. The most accurate, but also the most administratively costly, method would be for each moving plaintiff or the court to calculate the total monetary value by which each movant's stock in the company would decrease if the suit were to recover the full amount alleged by the

${ }^{160}$ See Part III.B.3.

${ }^{161} 15$ USC $\S \S 77 \mathrm{z}-1(\mathrm{a})(3)(\mathrm{B})(\mathrm{iii})(\mathrm{I}), 78 \mathrm{u}-4(\mathrm{a})(3)(\mathrm{B})(\mathrm{iii})(\mathrm{I})$.

${ }^{162}$ See Hansberry, 311 US at 45-46.

${ }^{16}$ See In re Seagate Technology II Securities Litigation, 843 F Supp 1341, 1361-62 (N D Cal 1994) (arguing that each continuing stockholder would want personally to recover for fraud and then prevent any other class members from recovering from fraud; thus, the interests of each continuing stockholder are antagonistic to the interests of every other plaintiff and so each would require his own subclass). Two reasons for rejecting this argument are that FRCP 23(b)(1) permits class actions for "limited fund" cases, such as where the defendant is bankrupt and each plaintiff will receive only a portion of what she is owed. In those cases, every plaintiff has an interest in minimizing the recovery of all other plaintiffs, in order to ensure that the defendant has enough money to pay her own claims, but class actions are permitted without the requirements of subclasses. Also, as the court later concludes, "certain minimum levels of antagonism" must be tolerated within either a class or subclass in order to have class actions at all. Seagate, 843 F Supp at 1366. 
plaintiffs. ${ }^{164}$ If this amount is greater than the share of the recovery that the movant would gain if the suit were successful, then the movant has an incentive to reduce the recovery and should be placed in one subclass. Likewise, if this amount is less than the share of recovery that the movant would gain if the suit succeeds, then the movant has an incentive to maximize recovery and should be placed in another subclass. While calculation of the decrease in the value of the movant's stock may be difficult, parties in securities fraud actions often employ economic experts ${ }^{165}$ who could construct roughly accurate numbers.

A simpler standard for courts to apply is a de minimis standard, where the dividing line between the shareholders with a substantial interest and those without is whether the plaintiff's recovery is, for example, five or ten times the value of stock he currently holds. While this test is less precise at separating the plaintiffs into subclasses according to their interests to pursue the litigation to its full extent, this test is far easier to apply than the first one. While some courts object to the difficulties of distinguishing between current and former stockholders because of the difficulties of finding a dividing line, ${ }^{166}$ either of these methods would permit a rough division of the classes without imposing costs severe enough to deter class actions. After using one of these methods, or a completely different one, the court would then appoint a lead plaintiff for each group who would conduct settlement negotiations and plot litigation strategy for their respective groups.

\section{CONCLUSION}

Private actions under the securities laws are an essential tool to combat securities fraud. However, Congress determined that such actions were perverted by plaintiff's attorneys who controlled the litigation and were not monitored by any client. The lead plaintiff provision of the PSLRA was enacted to take control away from attorneys, principally by encouraging those plaintiffs with the largest financial interest (and especially institutional

\footnotetext{
${ }^{16}$ The greatest amount of recovery alleged by any of the movants for the class as a whole should be used (unless the judge determines that this amount is unreasonable), because those without a significant stock interest will seek the highest amount of recovery possible, and those with a significant stock interest would seek less damages than this highest amount if a verdict or settlement in this amount would cause the value of their stocks to decrease by more than their share of the recovery.

${ }^{150}$ See, for example, Alexander, 41 UCLA L Rev at 1425-26 (cited in note 149).

${ }^{166}$ See Ziemack v Centel Corp, 164 FRD 477, 482-83 (N D Ill 1995); Seagate, 843 F Supp at 1364.
} 
investors) to assume control of the litigation. Courts should interpret the PSLRA so as to fulfill this congressional purpose. In ruling on class certification motions, courts have already rejected many of the objections raised by those who oppose the presumptive lead plaintiff, such as those based on sophistication or independent fiduciary duties. Courts should limit the aggregation of plaintiffs' losses in order to prevent lawyers from assembling groups of small claimants who may cede control of the litigation to counsel. However, in cases where both current and former stockholders sue, courts should appoint separate lead plaintiffs to ensure adequacy of representation. 